\title{
ACCESSIBILITY OF INFORMATION TECHNOLOGIES IN THE RESTING HOME
}

\author{
Özlem Çakır ${ }^{1}$ \\ ${ }^{1}$ Department of Computer Education and Instructional Technology, Ankara University, \\ Ankara, Turkey \\ ocakireankara.edu.tr*
}

\begin{abstract}
In Turkey, resting homes are opened increasing number day by day, by years in accordance with the requirement of increasing old age population. Information and communication technology are so important for these old people for communicating to other people, learning, and hobbies, ... etc. In this study, accessibility conditions of elderly people to information and communication technologies in these resting homes. For this reason, answered the questions: For the individuals who live in the resting homes in Turkey: a) Is there a computer lab that they can access?, b) How many computers are there that they can access?, c) Do they have internet access?. When it is checked whether there are computer rooms in resting homes, it is seen that there is a computer room in 28 (13.93\%) homes out of 201 resting homes. When the number of computer per resting home is checked (201/137), it is found out that this number does not refer to even 2 computers. As a result, it can be said that there are very few computers in resting homes, which elderly people can access. 28 resting homes, which have a computer room, have also internet access. However, there is internet access in all resting homes because of official proceedings. Only 110 resting homes allow elderly people living there use the internet (54.73\%).
\end{abstract}

\section{KEYWORDS}

Resting Home, Computer Accessibility, Internet Accessibility

\section{INTRODUCTION}

Old age can be defined as the physical change through the alteration of the structures and the deceleration of the organism and the functions of the systems that the organism inhold and psychological deformation process that arises by the effects of this physical change and social environment [1]. The World Health Organization (WHO) accepts old age phase as 65 and over and accepts this age limit as the transition period from independent state to dependent state in terms of demographic aspects [2]. According to the classification of the WHO, the ages 45-59 are classified as middle -aged, 60-74 as old, 75-89 as elderly and 90 and over as senility [3].

According to the latest population census that was carried out in 2000 in Turkey, the population was 67.803.927. Total population growth rate in Turkey in 2005 was $12.6 \%$ o. Population distribution in Turkey according to the age groups and gender is summarized in Table 1. As shown in Table $1.8 .23 \%$ of the population in Turkey forms old-age class. This rate corresponds to 5.711.618 people [4].

\footnotetext{
* This paper presented in IV.International Congress of Educational Research. Y1ldız Technical University. 4-7 May 2012 stanbul /Türkiye DOI : $10.5121 /$ ijcsit.2012.4601
} 
Old-age phase is a sensitive period in terms of physiological and psychological aspects of human life [1]. Another depressive symptom is the feeling of uselessness and the state of feeling worthless because of the factors that cause the individual become inactive such as a decline in physical and mental functions, a loss of productivity quality and retirement [5]. With children leaving home and/or retirement, the elderly who thinks that they get through their environmental and social purposes gradually decrease their social activities, communications and daily activities...etc. These kinds of problems that the elderly experience in socializing and activity affect their future plans in a negative way. Future anxiety that they have before old age replaces fear of death [6].

Table 1. The population in Turkey [4].

\begin{tabular}{|l|l|l|l|l|}
\hline The age group & Male & Female & Total & Rate $(\%)$ \\
\hline $0-4$ ages & $3,396,690$ & $3,188,132$ & $6,584,822$ & 9.7 \\
\hline 5-9 ages & $3,485,746$ & $3,270,871$ & $6,756,617$ & 9.9 \\
\hline $10-14$ ages & $3,570,657$ & $3,307,999$ & $6,878,656$ & 10.1 \\
\hline 15-19 ages & $3,691,218$ & $3,518,257$ & $7,209,475$ & 10.6 \\
\hline 20-24 ages & $3,426,714$ & $3,263,432$ & $6,690,146$ & 9.8 \\
\hline 25-29 ages & $2,976,30$ & 2,918825 & $5,895,255$ & 8.6 \\
\hline 30-34 ages & $2,552,370$ & $2,457,285$ & $5,009,655$ & 7.3 \\
\hline 35-39 ages & $2,453,579$ & $2,400,808$ & $4,854,387$ & 7.1 \\
\hline $40-44$ ages & $2,083,531$ & $1,985,225$ & $4,068,756$ & 6.0 \\
\hline $45-49$ ages & $1,710,757$ & $1,658,012$ & $3,368,769$ & 4.9 \\
\hline $50-54$ ages & $1,356,31$ & $1,360,58$ & $2,717,349$ & 4.0 \\
\hline $55-59$ ages & $1,016,254$ & $1,042,168$ & $2,058,422$ & 3.0 \\
\hline $60-64$ ages & 864,299 & 964,989 & $1,829,288$ & 2.7 \\
\hline 65-69 ages & 794,881 & 850,636 & $1,645,517$ & 2.4 \\
\hline $70-74$ ages & 517,870 & 654,773 & $1,172,643$ & 1.7 \\
\hline $75-79$ ages & 254,43 & 323154 & 577,97 & 0.8 \\
\hline $80-84$ ages & 98,797 & 147,895 & 246,692 & 0.3 \\
\hline $85+$ & 83,572 & 132,928 & 216,500 & 0.3 \\
\hline Unknown & 12,536 & 10,845 & 23,381 & 0.03 \\
\hline Total & $34,346,735$ & $33,457,192$ & $67,803,927$ & 100 \\
\hline
\end{tabular}

The fear of losing what is left behind leads to the consideration of social death along with biological death and this causes stress in the elderly. All the wealth that they earn through all their lives will be shared and their hopes and values will disappear. Even if not in biological aspects, this damages the expectations of survival in terms of social aspects such as leaving a mark behind, being remembered and being memorable...etc. The feelings that mean social death for a human being overcome the fear of biological death from time to time. In this respect, thoughts and anxieties in the city and in the country sampling are both very high and the rates are very close to each other. It is $95 \%$ in the city and $90 \%$ in the country. Although biological death seems to be accepted, social death becomes a problem [7].

While in traditional societies, the fact that the experience of elderly population is taken into consideration, their life experiences are appreciated and their authority lead the way are beyond argument but in changing conditions today, in modern culture even according to some people in postmodern culture, elderly population are alienated and gradually attracted to an inactive state. Due to the heavy conditions of urban life, being alienated, elderly people who cannot get necessary attention from their families started living in resting homes. 
According to the multi-factor model of the needs of elderly people for continued well-being [8], health and wellness, hobbies, mobility, working life, information and learning and social interaction among these are the elements that create well-being person and provides a highquality life for individuals to be able to continue their lives in a good way (Figure 1). Information and communications technologies can be used so that the elderly population that will increase in the upcoming years will be able to pass this phase free of problems.

Figure 1. A multi-factor model displaying the needs of (elderly) persons for continued well-being [8].

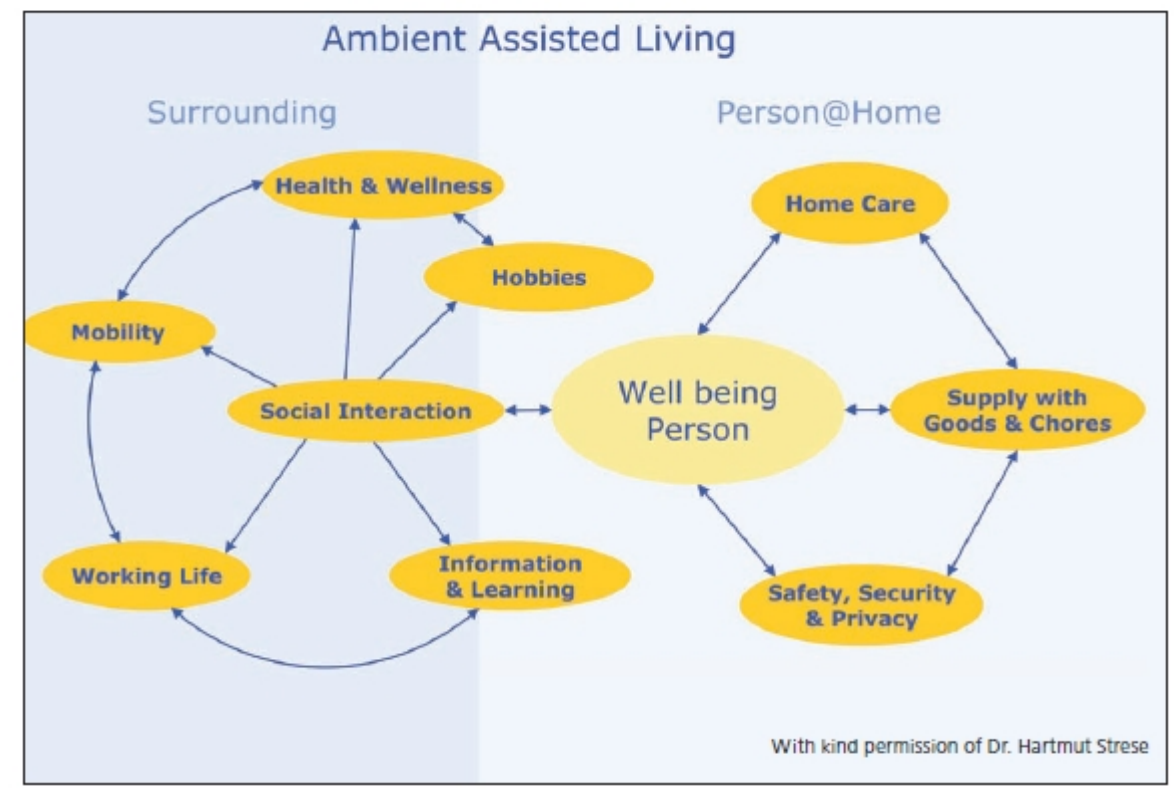

\subsection{Health and wellness}

In information and communication technologies, Home Care is defined as the most important factor that is related to Safety Connections and Communication Participants health, information, and communication technologies. Elderly people can access the information, which are related to their health problems through internet [9]. As well as health card, clinical background that is processed in the computer, elderly people can get help about their health from doctors through webcam [10]. In this way, health expenses can also be reduced [11].

\subsection{Safety, security and privacy}

Elderly people's staying home alone can endanger their own and other people's safety. For the maintenance of the security and safety at home, there can be alarm systems for the circumstances in which someone can be in danger such as gas or electricity leakage [10].

\subsection{Hobbies}

For many people, hobbies are very important pastimes for personal growth, recreation and social interaction [9]. Usual activities are games, music, reading, walking, playing golf, collecting or just talking to people who are interested in the same hobbies...etc. Information and communication technologies can be helpful by providing an access to the information about their hobbies and to the people who are interested in them or finding a new hobby for elderly people. 


\subsection{Mobility}

For elderly people's mobility problems and also for the family members who are away from them, internet tools such as internet-based webcams, message texting system and e-mail provide necessary virtual social support [9].

\subsection{Information and learning}

Today's information and communication technologies (internet and interactive TV) provide people opportunities to be able to use wide limits of education and information systems without leaving their homes. Modern devices like mobile phones, handheld computers allow elderly people to get informed. Information is necessary for mental activities, saving/keeping/storing the information, continuity of the connection with the outer world and for personal growth [8].

\subsection{Social interaction}

The loss of efficiency because of aging, the death of a close friend, loneliness and alienation due to the isolation that is caused by aging are the typical states of old age. In many studies that are carried out $[9,12,13,14]$, the most frequent problem in old age is depression, which is caused by loneliness. In a study, which was done by Cohen and Syme [15], it was reported that elderly people who have high social interaction during their illnesses had recovered faster. Information and communication technologies can give the individuals who have difficulty in coming together a unique opportunity to socialize, overcome loneliness and establish social communication systems that can prevent alienation $[8,11,13]$. In the studies they carried out, Karavidas, Lim and Katsikas [8] stated that when elderly people increase their social communication through internet/computer, there are direct and positive effects in their life satisfaction.

Consequently, when the studies about the education of information and communication technologies are examined, it was said that information and communication technologies and wider social communication networks could be helpful in managing health expenses and overcoming depression and stress $[15,16,17,18,19]$.

In addition to these, internet provides people to be in contact with others and affect social communication systems [11]. Information and communication technologies can help elderly people improve their life quality, stay healthy and live on their own for longer periods [20].

The number of resting homes that are opened by years in accordance with the requirement of increasing old age population, their capacities and the number of people who are staying in those homes are shown in Table 2. According to the latest information about resting homes in the web page of General Directorate of Disabled and Elderly Services, there are 293 resting homes. Some of them exist under the administration of General Directorate of Disabled and Elderly Affairs Family and Social Policy Ministry. The others belong to people, minorities, associations and foundations, municipalities and other public institutions and organizations [21]. In this study, accessibility conditions of elderly people to information and communication technologies in these resting homes, which increase in number day by day is aimed to be reported.

In this respect, answers are searched for the following questions. For the individuals who live in the resting homes in Turkey:

A) Is there a computer lab that they can access?

B) How many computers are there that they can access?

C) Do they have internet access? 


\section{METHOD}

Because this study aims to reveal the present conditions about the information and communication technologies in resting homes in Turkey, it is in screening model.

According to the information, which is obtained from the General Directorate of Disabled and Elderly, the distribution of the number of resting homes in Turkey, their capacities and the number of elderly people who are cared in these resting homes by years is as below (Table 2).

Table 2. The number and the capacity of elderly people cared between the years 2002-2011 in resting homes under the administration of (SSCP) General Directorate of Social Services and Child Protection Institution [21].

\begin{tabular}{|l|l|l|l|}
\hline Year & Number of resting home & Resting home capacity & $\begin{array}{l}\text { Number of elderly } \\
\text { cared }\end{array}$ \\
\hline 2002 & 63 & 6477 & 4952 \\
\hline 2003 & 63 & 6580 & 5188 \\
\hline 2004 & 62 & 6760 & 5389 \\
\hline 2005 & 66 & 7173 & 5603 \\
\hline 2006 & 69 & 7605 & 6082 \\
\hline 2007 & 70 & 7552 & 6477 \\
\hline 2008 & 79 & 8002 & 6773 \\
\hline 2009 & 81 & 8126 & 7220 \\
\hline 2010 & 97 & 9260 & 7979 \\
\hline 2011 & 99 & 9608 & 8511 \\
\hline
\end{tabular}

The number of resting homes has increased to 293 in the year 2012. The data of this study is obtained from 201 homes out of 293 resting homes that can be contacted in Turkey according to the information in the web page of General Directorate of Disabled and Elderly Services [21]. The distribution of resting homes according to the type of institution is given in Table 3 .

Table 3. Resting home institution type.

\begin{tabular}{|l|l|l|l|l|}
\hline Institution type & Number & \% & Contacted & \% \\
\hline $\begin{array}{l}\text { Resting Homes Under the General } \\
\text { Directorate of Disabled and Elderly Affairs } \\
\text { Family and Social Policy Ministry/State } \\
\text { Resting Homes }\end{array}$ & 102 & 34.81 & 77 & 38.31 \\
\hline Private Resting Homes & 124 & 42.32 & 79 & 39.30 \\
\hline Minorities' Resting Homes & 7 & 2.39 & 4 & 1.99 \\
\hline $\begin{array}{l}\text { Associations and Foundations Resting } \\
\text { Homes }\end{array}$ & 33 & 11.26 & 27 & 13.43 \\
\hline Municipality Resting Homes & 21 & 7.17 & 8 & 3.98 \\
\hline $\begin{array}{l}\text { Other Public Institutions and Organizations } \\
\text { Resting Homes }\end{array}$ & 6 & 2.05 & 6 & 2.99 \\
\hline Total & 293 & 100.00 & 201 & 100.00 \\
\hline
\end{tabular}

Information has been collected about their conditions related to information and communication technologies by contacting resting homes and descriptive analysis has been done. 


\section{FINDINGS}

The following data has been obtained in accordance with the research's purpose.

\subsection{The situation of computer labs in Turkey that elderly people living in resting homes can access}

When it is checked whether there are computer rooms in resting homes, it is seen that there is a computer room in $28(13.93 \%)$ homes out of 201 resting homes.

Table 4. Resting homes with a computer room.

\begin{tabular}{|l|l|l|l|}
\hline Institution type & With a computer & \% & Total \\
\hline $\begin{array}{l}\text { Resting Homes Under the Directorate of Disabled and } \\
\text { elderly services Family and Social Policy Ministry }\end{array}$ & 14 & 18.18 & 77 \\
\hline Private Resting Homes & 8 & 10.13 & 79 \\
\hline Minorities' Resting Homes & 0 & 0.00 & 4 \\
\hline Associations and Foundations Resting Homes & 6 & 22.22 & 27 \\
\hline Municipality Resting Homes & 0 & 0.00 & 8 \\
\hline Other Public Institution and Organization Resting Homes & 0 & 0.00 & 6 \\
\hline Total & 28 & 13.93 & 201 \\
\hline
\end{tabular}

\subsection{The number of the computers that elderly people living in resting homes can access}

Table 5. The number of computers in resting homes under the Directorate of Disabled and Elderly Services Family and Social Policy Ministry.

\begin{tabular}{|l|l|r|r|}
\hline City & Resting home's name & Capacity & $\begin{array}{r}\text { Number of } \\
\text { computer }\end{array}$ \\
\hline Afyonkarahisar & $\begin{array}{l}\text { Afyonkarahisar Resting Home Elderly Care and } \\
\text { Rehabilitation Center }\end{array}$ & 110 & 2 \\
\hline Antalya & Antalya Fethi Bayçın Resting Home & 163 & 4 \\
\hline Aydın & $\begin{array}{l}\text { Aydın Resting Home and Elderly Care } \\
\text { Rehabilitation. Center }\end{array}$ & 140 & 3 \\
\hline Bolu & Bolu zzet Baysal Resting Home & 60 & 4 \\
\hline Denizli & $\begin{array}{l}\text { Denizli Resting Home elderly Care and } \\
\text { Rehabilitation Center }\end{array}$ & 200 & 4 \\
\hline Karabük & Karabük Yücel Resting Home & 140 & 5 \\
\hline Kastamonu & Kastamonu Resting Home & 104 & 4 \\
\hline Kocaeli & Gölcük Municipality Resting Home & 40 & 7 \\
\hline Kocaeli & Kocaeli Resting Home & 104 & 4 \\
\hline Konya & $\begin{array}{l}\text { Konya Dr. smail Işık Resting Home Elderly Care } \\
\text { and Rehabilitation Center }\end{array}$ & 325 & 5 \\
\hline Manisa & Manisa Turgutlu Resting Home & 75 & 4 \\
\hline Mersin & Tarsus Resting Home & 54 & 8 \\
\hline Nevşehir & Nevşehir Hacı Bektaş Rıfat Kartal Resting Home & 40 & 6 \\
\hline Samsun & $\begin{array}{l}\text { Samsun Havza Resting Home and Rehabilitation } \\
\text { Center }\end{array}$ & 30 & 2 \\
\hline & Total & & 62 \\
\hline
\end{tabular}

When the number of the computers is checked in the resting homes with a computer, the data in following charts are obtained. 
International Journal of Computer Science \& Information Technology (IJCSIT) Vol 4, No 6, December 2012

Table 6. The number of computers in private resting homes.

\begin{tabular}{|l|l|r|r|}
\hline City & Resting home's name & Capacity & $\begin{array}{r}\text { Number of } \\
\text { computer }\end{array}$ \\
\hline \multirow{2}{*}{ stanbul } & Private Çengelköy Resting Home and Elderly Nursing & 55 & 3 \\
& Home & 17 & 2 \\
\hline stanbul & Private Erdem Resting Home and Elderly Nursing Home & 29 & 1 \\
\hline stanbul & Private Ferah Resting Home & 10 & 3 \\
\hline stanbul & Private Göksu Resting Home & 18 & 1 \\
\hline stanbul & Private Gülşah Resting Home and Elderly Nursing Home & 41 & 22 \\
\hline stanbul & Private Yeşilköy Resting Home & 26 & 1 \\
\hline zmir & Private Yaka Nursing Home and Resting Home & 22 & 1 \\
\hline Mersin & $\begin{array}{l}\text { Private Dr. Selahattin Palamut Resting Home and } \\
\text { Nursing Home }\end{array}$ & & 34 \\
\hline & Total & & \\
\hline
\end{tabular}

Table 7. The number of computers in resting homes of associations and foundations.

\begin{tabular}{|l|l|r|r|}
\hline City & Resting home's name & Capacity & $\begin{array}{r}\text { Number of } \\
\text { computer }\end{array}$ \\
\hline Ankara & $\begin{array}{l}\text { Private Akyurt Association Akyurt } \\
\text { Resting Home }\end{array}$ & 85 & 3 \\
\hline Antalya & $\begin{array}{l}\text { Antalya protection and social aid } \\
\text { association resting home for homeless } \\
\text { and helpless elderly people }\end{array}$ & 24 & 1 \\
\hline stanbul & $\begin{array}{l}\text { Yap1 Kredi Bank Corporation Members } \\
\text { Solidarity and Retirement Fund Resting } \\
\text { Home }\end{array}$ & 33 & 2 \\
\hline stanbul & $\begin{array}{l}\text { Rumelia Turks Culture and Solidarity } \\
\text { Association Resting and Nursing Home }\end{array}$ & 44 & 32 \\
\hline stanbul & $\begin{array}{l}\text { Darüşşafaka Maltepe Bağış̧̧lar Site } \\
\text { 2.Nursing Home }\end{array}$ & 39 & 2 \\
\hline Mersin & $\begin{array}{l}\text { Mersin Solidarity and Benevolence } \\
\text { Fund Resting and Nursing Home }\end{array}$ & 90 & 1 \\
\hline & Total & & 41 \\
\hline
\end{tabular}

When the number of computers that can be accessed is checked, it is seen that most of the resting homes do not have a computer although there are total 137 computers in 201 resting homes in total. It is seen that there is minimum 1 and maximum 32 computers in resting homes with a computer room. When the number of computer per resting home is checked (201/137), it is found out that this number does not refer to even 2 computers. As a result, it can be said that there are very few computers in resting homes, which elderly people can access.

\subsection{The situation of internet access for elderly people living in resting homes in Turkey}

When it is checked whether there is an internet connection, it is seen that there is an access to the internet in every resting home which has a computer. As it is seen in Table 4, resting homes under the Directorate of Disabled And Elderly Services of Family and Social Policy Ministry have 14 computers, private resting homes have 8 computers and associations and foundations resting homes have 6 computers. In these resting homes, there is also internet access. However, there are resting homes that offer internet access when computer is provided. Resting homes, which offers 
internet access to the elderly even though they do not have computers within the institution, are given in Table 8.

Table 8. The number of resting homes that have the internet access.

\begin{tabular}{|l|l|l|l|}
\hline Institution Type & With Internet & \% & Total \\
\hline $\begin{array}{l}\text { Resting Homes under the Directorate of Disabled and } \\
\text { Elderly services of Family and Social policy Ministry }\end{array}$ & 38 & 49.35 & 77 \\
\hline Private Resting Homes & 46 & 58.23 & 79 \\
\hline Minorities' Resting Homes & 2 & 50.00 & 4 \\
\hline Associations and Foundations Resting Homes & 18 & 66.67 & 27 \\
\hline Municipality Resting Homes & 0 & 0.00 & 8 \\
\hline Other Public Institution and Organization Resting Homes & 6 & 100.00 & 6 \\
\hline Total & 110 & 54.73 & 201 \\
\hline
\end{tabular}

28 resting homes, which have a computer room, have also internet access. However, there is internet access in all resting homes because of official proceedings. Only 110 resting homes allow elderly people living there use the internet $(54.73 \%)$.

\section{Discussion}

In Turkey, there are few computer rooms within resting homes. Only 28 out of 201 resting homes have a computer room and there are only 137 computers, which have internet access. With the information obtained as a result of the contact with the resting homes, it is understood that elderly people in two resting homes bought computers with their own money and accessed to the internet via wireless modem. They asked for instructors from Community Centers for a computer course. This training includes courses such as using web cams, how to communicate with their family members and friends and learn how to use social networks. Nowadays, there are very few initiatives/attempts like these.

In the researches about the elderly, it is determined that elderly people living in resting homes spend their times by chatting, watching TV and going for a walk/traveling [5; 22, 23]. In this ambiance, it is necessary to look for an answer to the question whether there are any other activities in resting homes that elderly people do not prefer doing.

Video viewing can be done even with very few existing computers, and texts that they find it hard to read can be magnified or they can be recorded through some programs. Elderly people living in resting home can overcome their physical handicaps with the help of information and communication technologies.

As mentioned above, information and communication technologies help the elderly deal with the stress, reduce the level of depression and manage health expenses [11]. Moreover, innovative information and communication technologies solutions usually enable people to solve the problems such as memory loss, poor sight, hard of hearing and immobility that are usually faced with aging [20]. Information and communication technologies can be used in the areas such as mobility, health and social communication/support. However, it is necessary to increase the access to information and communication technologies. 


\section{REFERENCES}

[1] Dönmez, G. (2010). Factors affecting quality of life in the elderly.Unpublished master thesis., Physical Therapy and Rehabilitation Program, Institute of Health Sciences, Abant Izzet Baysal University, Turkey.

[2 ]WHO (1998). The Report of the World Health Organization, World Health Organization Publications, Genova 1998;7.

[3] WHO (1999). The Report of the World Health Organization. [Web: http://didb.saglik.gov.tr/yayinlar/1999.Date: 15.03.2012]

[4] Turkish Statistical Institute (2007). [Web: http://www.tuik.gov.tr/, Date: 15.03.2012]

[5] Bahar,A., Tutkun, H. ve Sertbaş,G. (2005). The determination of the level of anxiety and depression of old people who live in the nursing home. Anatolian Journal of Psychiatry. 6:227-239.

[6] Erdoğdu, M Y. ve Özkan, M. (2007). The Relationships between death anxiety with dispositional symptoms and socio-demographic variables of individuals from different religions. Journal of Inonu University, Medical Faculty, 14, No 3.

[7] Maden, A. (1991). Psychosomatic and cultural characteristics of old age. Ankara University, Journal of the Faculty of Language, History and Geography. 35 (1). 181-189. DOI:10.1501/Dtcfder_0000001113.

[8] Gaßner,K., \& Conrad, M.(2010). ICT enabled independent living for elderly. Druckerei Feller, Teltow. ISBN 978-3-89750-160-7

[9] Karavidas, M., Lim, N. K., \& Katsikas, S. L. (2005). The effects of computers on older adult users. Computers in Human Behavior 21. 697-711.

[10] Hernández-Encuentra, E., Pousada, M. \& Gómez-Zúñiga, B. (2009): ICT and Older People: Beyond Usability, Educational Gerontology, 35:3, 226-245 http://dx.doi.org/10.1080/03601270802466934, Date: 15.03.2012].

[11] Hogeboom, D. L., McDermott, R. J., Perrin, K. M. , Osman, H. \& Bell-Ellison, B. A. (2010). Internet Use and Social Networking Among Middle Aged and Older Adults, Educational Gerontology, 36:2, 93-111.[ Web: http://dx.doi.org/10.1080/03601270903058507, Date: 15.03.2012].

[12] Cohen, C. (2001). Guiding seniors. Internet, 64(2), 50-53.

[13] Robinson, J. P., Kestnbaum, M., Neustadtl, A., \& Alvarez, A. (2000). Mass media use and social life among Internet users. Social Science Computer Review, 18(4), 490-501.

[14] White, H., McConnell, E., Clipp, E., Bynum, L., Teague, C., Navas, L., et al. (1999). Surfing the net in later life: A review of the literature and pilot study of computer use and quality of life. Journal of Applied Gerontology, 18(3), 358-378.

[15] Cohen, S., \& Syme, S. L. (1985). Issues in the study and application of social support. In S. Cohen \& S. L. Syme (Eds.), Social support and health. Orlando, FL: Academic Press.

[16] Berkman, L. F. (1985). The relationship of social networks and social support to morbidity and mortality. In S. Cohen \& S. L. Syme (Eds.), Social support and health. Orlando, FL: Academic Press.

[17] Crawford, G. (1987). Support networks and health-related change in the elderly: Theory-based nursing strategies. Family \& Community Health, 10, 39-48.

[18] Lubben, J., \& Gironda, M. (1996). Assessing social support networks among older people in the United States. In H. Litwin (Ed.), The social networks of older people: A cross-national analysis. London: Praeger.

[19] Seeman, T. E. (1996). Social ties and health: The benefits of social integration.Annals of Epidemiology, 6, 442-451.

[20] Pieri, M. \& Diamantinir, D. (2010). Young people, elderly and ICT. Procedia Social and Behavioral Sciences 2 (2010) 2422-2426.

[21] General Directorate of Elderly and Disabled (2012). [Web: http://www.ozurluveyasli.gov.tr, Date: 15.03.2012]

[22] Fadıloğlu Ç, Esen A, Karadakovan A (1992). Examination of activities of daily living and health conditions of the elderly living in resting home: "Healthy Aging ". International Council of Nursing 1992 Book of the symposium theme, School of Nursing, Hacettepe University. 26-27 Nowember 1992, Prime Ministry Social Services Publications, Ankara, p.139-148

[23] Lee, R.E., \& King, A.C. (2003). Discretionary time among older adults: how do physical activity promotion interventions affect sedentary and active behaviors? Annals of Behavioral Medicine, 25 (2), 112-119. 
International Journal of Computer Science \& Information Technology (IJCSIT) Vol 4, No 6, December 2012

\section{Authors}

Dr. Çakır is an assistant professor in Ankara University, in Department of Computer Science and Instructional Technology. She studies on accessibility of the technology. She also studies computer assisted learning, adaptive learning systems, personalized learning systems, social network, and internet addiction.

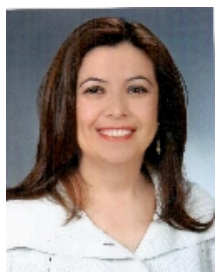

